\title{
Gender Equity as a means of Promoting National Development: A Sociological Reflection
}

\author{
Titilade Muyibat Ajayi, Dr. \\ Osun State College of Technology, Esa Oke. Osun State.Nigeria, titilade.muyibat@gmail.com
}

\begin{abstract}
The development of a nation entails the contributions of both men and women. However, all over the world, there are imbalances of power between men and women thus placing some obnoxious socio-cultural and political factors encouraging men's superiority over women. For example, job opportunities, recruitment strategies and political conditions have so much stereotyped the nature of women jobs and participation in nation building. This paper, therefore, looks at the sociological analysis of issues concerning women in wages, employment and politics as it is being affected by sex differential since women have been so adversely affected. The paper highlights the undesirable factors culminating to sex segregation and the aftermath effects. It also sets out to justify the need to give equal opportunity to both men and women in order to promote national development. The paper concludes that national development is a multidimensional process which can be accelerated by making efforts to bridge the socio-cultural and political gaps between the males and females in a healthy society.
\end{abstract}

KEYWORDS: Gender equity, Sex segregation, National development

\section{Introduction}

Historically, women have been discriminated against except in a few developed countries where women are partially recognized. Women are grossly under-represented in most areas of public life. Though in the developed countries of the world few females in comparison to their male counterparts have been elected or appointed as heads of state or government, the story is quite different in Africa except in the case of Ellen Johnson Sirleaf who was elected the 24th President of Liberia between 2006 and 2018. She was the first and only female president in Africa to date. In other African countries, no other woman has ever become president or state governor. Even the post of deputy governor characteristically allotted for women account for less than five percent in few countries like Nigeria, Ghana, and Sierra-Leone.

In the same vein, women are poorly represented when it comes to managerial and executive positions in many ramifications of life. According to United Nations report of 19th-30th August 1974 World Conference on population, women constituted more than half of world population it means that more than half of the world is marginalized in terms of contribution to national development. No wonder, so much poverty still prevails all over the world. The imbalanced representation and gender inequality negate national development hence there is a need for serious efforts to bridge the gender inequality gap. As homemakers, women are the custodian of social, cultural and fundamental values and desired positive changes are best achieved through their participatory efforts. In fact, it could be asserted without fear of contradiction that full community development is not possible without the understanding, cooperation and effective participation of women. No nation could make a meaningful headway socially, politically, culturally or economically without the female sector empowerment.

This paper is an attempt to provide a sociological analysis of factors of gender segregation and its aftermath effects, need for equal opportunity for both male and female genders in a given nation by bridging the gender inequality gap and thereby creating a healthy society for accelerated national development and growth.

\section{Factors and Effects of Sex}

SEGREGATION. It should be noted that gender as a concept and usage over the years by planners, educators, policy makers, and government has been appreciably misconstrued. At the mention of 'gender' many immediately suppose that reference is being made to women and their affairs or vice versa. The term gender is not synonymous with women, nor is it shorthand for classification into 
women and men. As against the archaic impression, gender is a system of roles and relationship between women and men that are not determined by nature. For instance, Awopegba (2004) defines gender as a concept, a condition, a category, an adjective and a component which refers to a socially learned behavior and expectation associated with males and females. It is no gainsaying that men and women are biologically different, but all cultures in different societies interpret and elaborate these inherent biological differences into a set of social expectations about what behaviors and activities are appropriate for them, and what rights, resources and even power they possess. Hence, due to discrimination on gender basis which remains pervasive in many aspects of life worldwide, gender construction is flexible and differs from place to place. Sherry B. Ortner (1974) also attempts to provide a general explanation for the universal devaluation of women. She claims that it is not biological factor as such that ascribes women to their status in society but the way in which every culture defines and evaluates them. The inequality between women's and men's positions results from perceptions and is perpetuated by complex combination of factors. Such factors include not only material variables but also a range of ideological determinants among which gender is particularly important.

First and foremost, monopoly of power by men is a major factor that accounts for gender inequality or sex segregation in a given society. According to Fox (1996), men by nature monopolize positions of power and opportunities in the society. Fox stressed that gender roles are culturally rather than biologically determined. Evidences from a number of different societies show that there are no tasks apart from child bearing which are performed exclusively by females. Biological characteristics do not bar women from any particular occupation. Even the mother role is a cultural construction. Women over the years have been made to accept male superiority and supremacy through the process of socialization.

Another factor is social placement which is usually social and physical environmental influence that depends on societal perception. The perceptions differ in different societies. Oakley (1987) saw placement as the determinants of gender roles. According to her, not only is the division of labour by sex not universal but there is no reason why it should be claimed that some are exclusive female roles and that biological characteristics bar women from particular jobs. In traditional Aloresa society, due to their order of social placement, women were largely responsible for the cultivation and collection of vegetables hence, economically productive than their men. Oakley further notes that a large body of research shows that the employment of the mother has no detrimental effects on the child's development. She stresses that working mothers can enjoy their children more than full time in some cases due to the joy derived from job satisfaction. Whichever way it is viewed, gender inequality is an impediment to national development and growth.

Problem of low female education when compared with males affects the volume of female in some employments. Education prepares an individual for employment and leadership roles and managerial responsibilities. In fact, the higher the level of education, the better for management positions leadership roles.

It is very saddening to note that the pattern of female empowerment is vertically distorted. Only small proportions of women occupy top jobs in management and administration. Even in occupations where women are well represented and which offer a career structure, they tend to be confined to junior levels. For example, women teachers are concentrated in primary and middle schools or colleges while smaller proportions are found in graduate colleges. Despite a series of conferences over the years to improve a lot of women on education, female access to high quality education is still a major concern. For instance, there have been many conferences and summits on women and girlchild education among which are the following:

1. Conference and summit on women in Nairobi (1985)

2. Conference and summit on girl -child in New York (1990)

3. Janeiro(1992) on women rights and in

4. Vienna (1993)

5. Conference in Cairo (1995). 
All the above had the objectives of achieving equality, development and peace. To ensure the full employment of woman and good education for the girl-child, efforts should be made to:

a. take all necessary measures to eliminate all forms of discrimination against women and the girl-child

b. remove obstacles to gender equality with advancements and empowerment of women

c. encourage men to participate fully in all actions toward equality

d. promote women's economic independence

It was pointed out that of all resolutions made at the 1995 Beijing World Women Conference, the one that most elicit our support and commendation above others for the attainment of parity with the men folk, is promotion of people-oriented, sustainable development including sustained economic growth through the provision of life-long education, literacy and training for the girl-child.

Challenges of personal life and stigmatization affect woman climbing up. For example, in many counties, there is the belief that no reasonable and responsible woman will ever dabble into politics. The women are at the disadvantage of attending political meetings where vital decisions are being taken. Some political parties hold sensitive meetings in the night which makes it difficult for the women folk to participate talk less of being short listed for any appointment. It is saddening to realize that this happens deliberately in order to edge the women out. Even the few women who manage to climb up the ladder are being frustrated by men under them who hate taking instructions from women.

Furthermore, the traditional roles of women strengthen gender inequality. For many years women were made to believe that their rightful place was in the home as housewives producers and minders of children. They were to stay at home and inculcate in their children the virtues of life while their husbands carried out tasks such as politics and governance thereby rendering the female child second class element. With this most women give in to their so-called subordinate status in the society and this eventually affects their contributions to national development and growth.

The employment discrimination act which most countries put up to protect working women have not been adequately functioning. Although few working women are covered by employment discrimination act, majority of them are not so lucky because many employers comply in only principle. Women working for some companies have not been enjoying the same protection because the face of gender discrimination has been evolving from the phrase like: 'men only need apply' type of case to those involving more covert discriminatory behaviors which the courts have also had to evolve the types of claims allowed under such discrimination acts. In today's society we have expression like 'you just weren't right for the job, we have found someone more qualified' or 'you didn't have the managerial skills we were looking for'. In all of these, the discrimination is hidden behind the expression. Due to covert intention, it is difficult to prove discrimination and most of the evidences are in the hands of the employers. Courts have created what is termed a 'prima facie' case or a list of required evidences that raise an inference of discrimination and allows a lawsuit to proceed without direct evidence of intentional illegal behaviors. Women's contribution to the economy has led to their marginalization in the nation's planning process. This neglect was partly due to the assumption that women will benefit via the 'trickle down' effect from their husbands.

Now, going by various definitions of national development, gender equality and women empowerment is imperative. Todaro (2014) says "development is a multidimensional process involving changes in structure, attitude and in situation as well as the acceleration of economic growth, reduction inequality and the eradication of absolute poverty". In order to accelerate development, efforts must be made to put in place among many things: bridging the socio-cultural, educational and political differences between the males and females in a healthy society. Ajayi (2005) saw economic development as the process whereby a country's real per capita gross national product or income increases over a sustained period of time by every sector, women inclusive. Whatever affects women will have great impact on the society and all individuals. There have been records of credible contributions of women in the emancipation of a nation and democratization, which are of immense importance to national development. For instance, Ellen Johnson Sirleaf was saddled with leadership not in her country alone but also on all Economic community of West Africa States (ECOWAS) with fifteen member countries. Angela Macon of Germany is also another woman of 
international influence while Margret Thatcher of Great Britain can never be forgotten in the history of the world at large. Women have been found to be performing in many high positions where they are elected or appointed to act.

The table below of females appointed or elected as heads of government or executive presidents is a clear picture of female marginalization.

Table 1. Females Appointed or Elected As Presidents/Heads of Government

\begin{tabular}{|l|l|l|l|}
\hline S.N & \multicolumn{1}{|c|}{ Country } & \multicolumn{1}{c|}{ Year } & \multicolumn{1}{c|}{ Name } \\
\hline $\mathbf{1}$ & Ukraine & $1917-1918$ & Eveheniya Bob-danivina Bosh \\
\hline $\mathbf{2}$ & Toka & $1940-1944$ & Khertek Anchimag \\
\hline $\mathbf{3}$ & China & $1968-1972$ & Song Qingling \\
\hline $\mathbf{4}$ & Israel & $1969-1974$ & Golda Meir \\
\hline $\mathbf{5}$ & Argentina & $1974-1976$ & Maria Estella \\
\hline $\mathbf{6}$ & Bolivia & $1979-1980$ & Lidia Aguilera Tejada \\
\hline $\mathbf{7}$ & Iceland & $1980-1996$ & Vigdis Finnbogadottir \\
\hline $\mathbf{8}$ & Malta & $1982-1987$ & Agatha Barbara \\
\hline $\mathbf{9}$ & France & $1982-1985$ & Lucett Chevry \\
\hline $\mathbf{1 0}$ & Philippines & $1986-1992$ & Maria Corazon \\
\hline $\mathbf{1 1}$ & Nicaragua & $1990-1997$ & Violeta Barrios \\
\hline $\mathbf{1 2}$ & Ireland & $1990-1997$ & Mary Robinson \\
\hline $\mathbf{1 3}$ & Republic of Spaska & $1996-1998$ & Bilgana Plavsic \\
\hline $\mathbf{1 4}$ & Ireland & $1997-2011$ & Mary McAleese \\
\hline $\mathbf{1 5}$ & South Korea & $2013-2017$ & Park Geunhyne \\
\hline $\mathbf{1 6}$ & Malawi & $2012-2014$ & Joyce Banda \\
\hline $\mathbf{1 7}$ & Kosovo & $2014-2016$ & Atifete Jahaga \\
\hline $\mathbf{1 8}$ & Brazil & $2011-2016$ & Dilma Rouseff \\
\hline $\mathbf{1 9}$ & Costa Rica & $2010-2014$ & Laura Chunchilla \\
\hline $\mathbf{2 0}$ & Chile & $2006-2010$ & Michelle Jeria \\
\hline $\mathbf{2 1}$ & Liberia & $2006-2018$ & Ellen Johnson Sirleaf \\
\hline $\mathbf{2 2}$ & The Philippines & $2000-2010$ & Gloria Macapagal Arroyo \\
\hline $\mathbf{2 3}$ & Finland & $2000-2012$ & Targa-Halonen \\
\hline $\mathbf{2 4}$ & Moscow & $1999-2004$ & Rodriguez Pananama \\
\hline & & &
\end{tabular}

Source: https//en.m.wikipedia.org>list. On Net

Table 1 depicts few women Heads of States or Government who were opportune to participate actively in the politics of their respective countries. The scope of this paper does not give room for enumeration of their contributions. However, history of national development would not be complete without reference to them. These were great women of influence who have performed resiliently excellently. Hence, if given opportunity, more women will perform more than expectation.

\section{Conclusion}

Contrary to the belief that women are inferior to men, women have been found to be equally productive in the society if given the opportunity but, unfortunately, women are unrecognized due to the ideas and definitions exerted by different societal culture. This paper has succinctly established that every culture has her own ideas and definitions of what is an appropriate behavior for men and women based on the history and values of that culture. Some argue that gender roles are formed from social pressure and prejudices. This is not because women have not been working but because their works have been more or less invisible. Unfortunately, in spite of women's increasing employment and contributions they still have a long way to go before their status can be at par with that of men. All over the world, there is a voice against the cycle of pains, low education of girl-child, humiliation and under representation of women. Now more than ever, there is a need for global attention to the plight of the females. In fact, any society that fails to annex the energy, flexibility and creativity of women will be disadvantaged. Overall, it can be conveniently concluded that discrimination against 
women remains a hindrance to economic prosperity and national development of today's societies as it has been from ages.

\section{Recommendations}

A number of recommendations follow from this discourse and seven of them are hereby highlighted for possible consideration in promoting gender equity as a means of fostering national development:

1. Both men and women should be seen as partners in the process of democratization, national development and growth. Some women are better managers if not for intimidation by men and other social factors. In order to facilitate national development and growth, men should be supportive rather than being intimidating.

2. Women should be prepared for senior and managerial responsibilities. Too often than not, women find out that they are channeled into staff positions that provide little or no access and visibility to corporate decision making. In order to prevent or stop this inequality, the societal systems should give women access to the core areas of economic and political developmental experiences.

3. Government at all levels must take the lead in the quest to make equal opportunity a reality for women.

4. Government and organizations should strengthen and enforce anti-discrimination laws by expanding efforts to end systematic discrimination.

5. Equal participation in public life by men and women should be promoted through sustainable re-orientation and education for the girl-child to ensure women emancipation and effective contributions toward national development and growth.

6. There should be provisions for economic and cultural conditions in order to facilitate favourable equal participation by women in all areas of economic activities.

7. Women should be empowered in all areas of life so that that they can contribute immensely to national development and growth.

\section{References}

Ajayi T. M. 2005. "Gender Equity in Education: Means of Promoting National Development in Nigeria." Journal of Current Studies in Education, Vol. 1 pp 175-178.

Ajayi T. M. 2008. "Effects of Sex Power Differential on Recruitment of female into Wage Employment." Journal of Arts and Social Sciences (JASS) Vol 1, pp 100-110.

Akinmadu, T. 1995. Obstacles to Women career Development: Sexual Harrassment in Employment in Nigeria. Civil Liberties Organization. Macmillan. Lagos, Nigeria.

Awopegba, P.O. 2004. The catalytic role of women in national development and management in Nigeria's Ibadan Centre for Local Government and Rural Development Studies.

Boron and Newman 1989. Organizational Barriers to Gender Equity: Sex Segregation of Jobs and Opportunity. New York, Aldine.

Fox H. L. 1996. Family, State and Social Policy. Macmillan, Baingstoke.

List of elected or appointed females Heads of State or Government . http//en.m.wikipedia.org>list

Oke. L. 2005. "Education Millennium Development Goals and the challenges of Gender Equity in the 21st Century in Nigeria." International Journal of Gender and Health Studies, Vol. $1 \& 2$ pp. 169- 183: The Development Universal consortia.

Qakley, Ann. 1987. Sex, Gender and Society. England: Tower Publishing Company Ltd.

Todaro, M. P. 2014. Guide for Economic Development. Longman, New York.

Otner B. S. 1974. "Is Female to as Nature to Culture?" in M.Z Rosaldo and Lamphere (eds) Women, Culture and Society. New York: University Press.

United Nations 1995. Fourth World Conference on Woman, Beijing. China (Report No. E.6 X1v. 13) Retrieved. http://www.un.org.womenwatch/daw/beijing/platf.

World Bank. 2005. Morocco Gender Sector notes for Annual Meetings. http//www.microenterpriseworks.org. 